\title{
Uprawy i hodowle bezglebowe a potrzeba ochrony gruntów rolnych z perspektywy zapewnienia bezpieczeństwa żywnościowego
}

\section{Wprowadzenie}

Grunty rolne stanowią główny czynnik produkcji rolnej. Ich swoistość kształtuje m.in. nieelastyczność zagregowanej podaży, nieprzemieszczalność, niepowiększalność, użyteczność, rzadkość, brak substytutów ${ }^{1}$. Są warunkiem bytności człowieka, dają podstawę do produkcji żywności, a co za tym idzie - realizują fundamentalne prawo do zapewniania odpowiedniego wyżywienia społeczeństwa ${ }^{2}$. Postęp cywilizacyjny, procesy urbanizacyjne oraz zmiany klimatyczne powodują, że zasoby gruntów rolnych dość szybko maleją wskutek zmiany ich przeznaczenia, degradacji właściwości produkcyjnych bądź całkowitej dewastacji środowiska ${ }^{3}$. Łączna powierzchnia gruntów pod zasiewami w Polsce konsekwentnie maleje, od stanu 8377273 ha z 2004 r. do 7511848 ha w 2015 r. ${ }^{4}$ Mając więc na uwadze konieczność zapewnienia

* Uniwersytet im. Adama Mickiewicza w Poznaniu.

${ }^{1}$ R. Marks-Bielska, A. Bieniek, Ekonomiczne i środowiskowe aspekty obrotu ziemia rolnicza w Polsce, „Studia Obszarów Wiejskich” 2018, t. 50, s. 227.

${ }^{2}$ M. Iwiński, A. Zydroń, M. Antkowiak, P. Szczepański, Wptyw nowelizacji ustawy o ksztattowaniu ustroju rolnego na rynek nieruchomości rolnych w województwie wielkopolskim, ,Studia i Prace Wydziału Nauk Ekonomicznych i Zarządzania” 2017, nr 49(1), s. 166.

${ }^{3}$ B. Jeżyńska, R. Pastuszko, Ramy prawne obrotu nieruchomościami rolnymi po 2016 roku. Opinie i ekspertyzy, Warszawa 2012, s. 3.

${ }^{4}$ M. Iwiński, A. Zydroń, M. Antkowiak, P. Szczepański, Wptyw nowelizacji ustawy..., s. 166. 
bezpieczeństwa żywnościowego, prawodawca przyjął instrumenty prawne służące ochronie gruntów rolnych.

W ostatnim czasie na świecie coraz częściej wykorzystuje się jednak metody upraw i hodowli, które nie wymagają udziału gleby, rozumianej jako wierzchnia warstwa gruntu. Rozwiązania te także w Polsce zyskują popularność. Wykorzystuje się je m.in. w szklarniowej uprawie warzyw, ziół i roślin ozdobnych. Należy zauważyć, że nawet w ponad połowie upraw szklarniowych pomidora i ogórka stosuje się metody z użyciem podłoży inertnych (wełna mineralna, pianka poliuretanowa) lub organicznych (kokos, węgiel brunatny) $)^{5}$.

Okoliczności te uzasadniają pochylenie się nad tematyką prawnych aspektów wykorzystywania bezglebowych metod upraw i hodowli na cele żywnościowe. Celem rozważań jest odpowiedź na pytanie, czy wobec coraz bardziej powszechnego stosowania tych technologii wciąż uzasadniona jest ochrona prawna gruntów rolnych, z uwagi na konieczność zapewnienia bezpieczeństwa żywnościowego.

\section{Ochrona gruntów rolnych a bezpieczeństwo żywnościowe}

Ochrona gruntów rolnych realizowana jest w Polsce dwutorowo: $z$ jednej strony jako ochrona jakościowa, z drugiej - jako ochrona ilościowa. Ochrona jakościowa polega przede wszystkim na zapobieganiu procesom degradacji i dewastacji gruntów rolnych oraz szkodom w produkcji rolnej powstającym głównie wskutek działalności nierolniczej i ruchów masowych ziemi, natomiast przepisy dotyczące ochrony ilościowej ukierunkowane są na kontrolę działań mogących skutkować uszczupleniem powierzchni gruntów rolnych w związku z wykorzystaniem ich na cele nierolne i nieleśne ${ }^{6}$.

W piśmiennictwie podkreśla się, że u podstaw aksjologicznych współczesnej regulacji prawnej dotyczącej ochrony gruntów rolnych leży troska o zapewnienie odpowiedniego areału gruntów potrzebnych do prowadzenia działalności wytwórczej w rolnictwie jako jednego z warunków bezpieczeństwa żywnościowego ${ }^{7}$. Wśród wielu przeszkód w zapewnieniu food security wymienia się zmniejszanie zasobów gruntów rolniczo wykorzystywanych

${ }^{5}$ Odpowiedź Sekretarza Stanu Ministerstwa Rolnictwa i Rozwoju Wsi z 28 października $2020 \mathrm{r}$. na Interpelację nr $12115 \mathrm{w}$ sprawie wprowadzenia na większą skalę upraw hydroponicznych, znak sprawy: KS.bb.058.2.2020, http://orka2.sejm.gov.pl/INT9.nsf/klucz/ATTBUVKFY/\%24FILE/ i12115-o1.pdf s. 1 [dostęp: 19.03.2021] (dalej: odpowiedź na interpelację nr 12115).

${ }^{6}$ P. Czechowski, K. Marciniuk, w: P. Czechowski (red.), Prawo rolne, Warszawa 2019, s. 393.

${ }^{7}$ Ibidem. 
wskutek przeznaczania ich na cele nierolnicze i wyłączania z produkcji rolnej ${ }^{8}$. Charakter ochronny mają również przepisy określające zasady i tryb obrotu nieruchomościami rolnymi ${ }^{9}$. Prawodawca w preambule do ustawy o kształtowaniu ustroju rolnego wprost wskazuje, że regulacje te uchwalono m.in. $\mathrm{w}$ trosce o zapewnienie bezpieczeństwa żywnościowego obywateli ${ }^{10}$. Wynika to z postrzegania własności rolniczej jako służącej zabezpieczaniu wyżywienia ludności oraz zapewnieniu odpowiedniej jakości żywności ${ }^{11}$.

Trzeba zaznaczyć, że pojęcie „bezpieczeństwo żywnościowe” jest różnie definiowane w literaturze oraz aktach i dokumentach o zróżnicowanym charakterze, lecz w ujęciu ogólnym oznacza dostęp ludzi do odpowiedniej żywności ${ }^{12}$. W piśmiennictwie rozróżnia się pojęcia bezpieczeństwa żywności i bezpieczeństwa żywnościowego, zwracając uwagę, że pierwsze zakłada przysługujące każdemu prawo do bezpiecznej żywności, drugie że każdy ma prawo do żywności ${ }^{13}$. Należy jednak stwierdzić, że prawo do żywności jest immanentnie związane z prawem do bezpiecznej żywności. Realizacja pierwszego z nich determinuje bowiem obowiązek zapewnienia bezpieczeństwa środków spożywczych dla zdrowia i życia konsumentów, a zatem rodzi konieczność realizacji prawa do żywności bezpiecznej. Z kolei ochrona zdrowia i życia człowieka przed zagrożeniami powodowanymi przez żywność może mieć miejsce dopiero po zapewnieniu dostaw środków spożywczych. Między wprowadzaniem żywności do obrotu a zapewnieniem jej bezpieczeństwa istnieje zatem swoiste sprzężenie zwrotne. Wprowadzanie żywności na rynek wiąże się z koniecznością spełnienia wymogów, jakie stawia prawo żywnościowe, a najważniejszym z nich jest zapewnienie jej bezpieczeństwa.

Procesy demograficzne i globalizacyjne, rozwój cywilizacyjny społeczeństw oraz wzrost industrializacji i urbanizacji sprzyjają stałemu zwiększaniu zapotrzebowania na rolnicze produkty żywnościowe ${ }^{14}$. Mając na względzie wzrost globalnego popytu na żywność w przyszłości, Unia Eu-

${ }^{8}$ R. Budzinowski, Współczesne wyzwania zwiazane z żywnościa i ich rola w ksztaltowaniu polityki rolnej i prawa rolnego, „Przegląd Prawa Rolnego” 2015, nr 2, s. 18.

${ }^{9}$ B. Jeżyńska, R. Pastuszko, Ramy prawne obrotu ..., s. 3.

${ }^{10}$ Preambuła do ustawy o kształtowaniu ustroju rolnego z 11 kwietnia 2003 r. (t.j. Dz. U. z 2020 r., poz. 1655 ze zm.).

${ }^{11}$ P. Litwiniuk, Ochrona własności rolniczej w świetle ustawy o ksztaltowaniu ustroju rolnego, „Przegląd Prawa Rolnego” 2019, nr 2, s. 50; T. Kurowska, Renesans wlasności rolniczej, „Przegląd Prawa Rolnego” 2014, nr 2, s. 32.

${ }_{12}$ K. Leśkiewicz, Prawo żywnościowe, Warszawa 2020, s. 6.

${ }^{13} \mathrm{~K}$. Leśkiewicz, Bezpieczeństwo żywnościowe i bezpieczeństwo żywności-aspekty prawne, „Przegląd Prawa Rolnego” 2012, nr 1, s. 181.

${ }_{14}$ P. Czechowski, K. Marciniuk, w: P. Czechowski (red.), Prawo rolne, s. 389. 
ropejska powinna być w stanie przyczynić się do jego zaspokojenia ${ }^{15}$. FAO szacuje, że wyżywienie dziewięciu miliardów ludzi, mających stanowić światową populację w 2050 r., możliwe jest jedynie przy zwiększeniu produkcji żywności o $70 \%{ }^{16}$. Prawie $80 \%$ gruntów rolnych na świecie jest już wykorzystywanych do hodowli zwierząt gospodarskich ${ }^{17}$, a przewiduje się, że globalna konsumpcja mięsa do $2050 \mathrm{r}$. wzrośnie o $26 \%{ }^{18}$. Światowa produkcja ryb musiałaby wzrosnać o 50\% w porównaniu do poziomu z 2006 r., aby sprostać zapotrzebowaniu określonemu na 2050 r. ${ }^{19}$

Jednym z największych współczesnych wyzwań jest zapewnienie długotrwałego bezpieczeństwa żywnościowego ${ }^{20}$ oraz przyczynienie się do zaspokojenia zwiększającego się zapotrzebowania na żywność ${ }^{21}$. Biorąc pod uwagę szczególne właściwości gruntów rolnych, jakimi są ich nieprzenoszalność oraz ograniczona dostępność, warto szukać rozwiązań w racjonalnym zwiększaniu innowacyjności branży rolno-spożywczej, w tym wykorzystywaniu innowacyjnych rozwiązań w rolnictwie i nieznanych dotychczas środków spożywczych, np. owadów ${ }^{22}$, tym bardziej że znaczenia nabiera trend związany z wykorzystywaniem coraz większych obszarów gruntów rolnych na wytwarzanie produktów niespożywczych, w tym biomasy ${ }^{23}$. Wobec tego obecna oraz przyszła Wspólna Polityka Rolna silnie akcentuje potrzebę wprowadzania innowacji oraz stanowi podstawę finansowania inwestycji i działań z zakresu transferu wiedzy ${ }^{24}$.

${ }^{15}$ Komunikat Komisji do Parlamentu Europejskiego, Rady, Europejskiego Komitetu Ekonomiczno-Społecznego i Komitetu Regionów WPR do 2020 r.: sprostać wyzwaniom przyszłości związanym z żywnością, zasobami naturalnymi oraz aspektami terytorialnymi, COM(2010) 672, s. 5 .

${ }^{16} \mathrm{http}: / /$ www.fao.org/livestock-environment/en/ [dostęp: 19.03.2021].

${ }_{17}$ Insect Protein - Feed for the Future, s. 7, http://www.proteinsect.eu/fileadmin/user_upload/ press/proteinsect-whitepaper-2016.pdf [dostęp: 19.03.2021].

18 The Parliamentary Office of Science and Technology, Novel Food Production, POSTNOTE 2015, nr 499, s. 3.

19 T. Laaninen, Insects - soon to be a regulated food?, EPRS (European Parliamentary Research Service), Members' Research Service PE 583.830, http://www.europarl.europa.eu/RegData/ etudes/ATAG/2016/583830/EPRS_ATA(2016)583830_EN.pdf, s. 1 [dostęp: 19.03.2021].

${ }^{20}$ R. Budzinowski, Wspótczesne wyzwania ..., s. 17.

${ }^{21}$ Komunikat Komisji do Parlamentu Europejskiego, Rady, Europejskiego Komitetu Ekonomiczno-Społecznego i Komitetu Regionów WPR do 2020 r.: sprostać wyzwaniom..., s. 2.

${ }_{22}$ Szerzej: Ł.M. Sokołowski, Entomofagia w świetle regulacji dotyczacych nowej żywności - wybrane aspekty prawne, „Przegląd Prawa Rolnego” 2017, nr 1, s. 98 i n.

${ }^{23}$ P. Czechowski, K. Marciniuk, w: P. Czechowski (red.), Prawo rolne, s. 390.

${ }^{24}$ Odpowiedź na interpelację nr 12115, s. 3. 


\section{Uprawy i hodowle bezglebowe}

W prawodawstwie unijnym oraz polskim nie wyodrębniono katalogu żywności innowacyjnej ani nie zdefiniowano pojęcia ,innowacje”. Współcześnie innowacje są pojmowane bardzo szeroko ${ }^{25}$. Za pioniera teorii innowacji uważa się Josepha A. Schumpetera, który rozumiał innowację jako wprowadzenie do produkcji wyrobów nowych lub udoskonalenie produktów już istniejących, wprowadzenie nowego lub udoskonalenie istniejącego procesu produkcyjnego, zastosowanie nowego sposobu sprzedaży lub zakupów, otwarcie nowego rynku, zastosowanie nowych surowców lub półfabrykatów oraz wprowadzenie nowej organizacji produkcji ${ }^{26}$. Definicja ta pozwala wyróżnić trzy zasadnicze rodzaje innowacji: produktowe, procesowe i usługowe ${ }^{27}$. Przedmiotem dalszych rozważań będą innowacje produktowe, czyli związane ze zmianami polegającymi na wprowadzeniu nowych produktów, oraz innowacje procesowe, czyli wprowadzanie nowych lub udoskonalonych procesów produkcyjnych ${ }^{28}$. Do tego rodzaju innowacji należy bowiem zaliczać żywność otrzymaną w wyniku upraw czy hodowli bezglebowych.

Istnieje wiele technologii upraw roślin, w których nie wykorzystuje się czynnika produkcji, jakim są grunty rolne. Można wyróżnić m.in. hydroponikę, tj. uprawę roślin w wodzie wzbogaconej składnikami odżywczymi zamiast gleby oraz aeroponikę, tj. system, w którym korzenie znajdują się w środowisku powietrznym, wysycanym w sposób ciągły lub przerywany rozdrobnioną pożywką $\mathrm{w}$ formie aerozolu lub mgły. Coraz większym zainteresowaniem cieszą się również stosowane w przestrzeni miejskiej, szczególnie tej mocno zurbanizowanej, ogrody i uprawy wertykalne. Jeśli natomiast chodzi o sposoby hodowli, w których nie wykorzystuje się gruntów rolnych, jako przykład można wskazać hodowlę owadów ${ }^{29}$.

Powyższe rozwiązania stosowane są od wielu lat. Za pierwowzór systemów hydroponicznych uznaje się wiszące ogrody Semiramidy w Babilonie,

${ }^{25}$ K. Kozłowska, Ocena wybranych aspektów innowacyjności polskich przedsiębiorstw, w: P. Urbanek, E. Walińska (red.), Ekonomia i zarządzanie w teorii i praktyce. Ekonomia i nauki o zarządzaniu w warunkach integracji gospodarczej, Łódź 2016, s. 170.

26 J.A. Schumpeter, Teoria wzrostu gospodarczego, Warszawa 1960, s. 104.

${ }^{27}$ K. Kozłowska, Ocena wybranych aspektów..., s. 171.

${ }^{28}$ Ibidem.

29 Sformułowanie „hodowla owadów” nie jest pojęciem prawnym. Choć pojęcie „hodowla” związane jest ze zwierzętami gospodarskimi (art. 2 pkt 5 ustawy z 10 grudnia 2020 r. o organizacji hodowli i rozrodzie zwierząt gospodarskich, t.j. Dz. U. z 2021 r., poz. 36 ze zm.), to stosuje się je również do owadów, przede wszystkim ze względu na brak właściwego słownictwa w języku polskim. 
a pierwsze wzmianki literaturowe na temat wykorzystywania tej metody do uprawy roślin pochodzą z XVII wieku ${ }^{30}$. W pierwszej połowie ubiegłego wieku hydroponika była już dobrze znanym i wykorzystywanym sposobem na uprawę roślin. Obecnie stanowi rodzaj produkcji szklarniowej, który stosowany jest w Europie Zachodniej, Ameryce i Azji. Spożywanie owadów opisano natomiast już w Biblii i Koranie. Aktualnie są one spożywane przez ludzi w wielu częściach świata, głównie w Azji, Afryce i Ameryce Łacińskiej. Stanowią część diety co najmniej dwóch miliardów ludzi, a ponad 1900 gatunków insektów stosowanych jest jako żywność ${ }^{31}$.

Uprawy i hodowle bezglebowe mają wiele zalet, wśród których można wymienić ich dużą wydajność ${ }^{32}$. Odpowiednio dobrane składniki odżywcze cyrkulujące w wodzie lub powietrzu mogą być lepiej dobierane, łatwiej dostępne i przyswajalne przez rośliny ${ }^{33}$. Pozwalają zatem uzyskać większe plony, dużo szybciej niż w przypadku roślin uprawianych w glebie, także $\mathrm{z}$ uwagi na brak mechanicznych ograniczeń dla systemów korzeniowych ${ }^{34}$. W uprawach hydroponicznych naturalnie nie występują przypadki ,zmęczenia gleby", a więc nie pojawia się problem z zachowaniem ciągłości upraw ${ }^{35}$. Uzyskanie wyższych plonów wynika też z możliwości zwiększenia gęstości produkcji rolnej i uprawy większej liczby roślin na jednostkę powierzchni $\mathrm{w}$ porównaniu $\mathrm{z}$ rolnictwem konwencjonalnym ${ }^{36}$. Jeżeli chodzi natomiast o hodowle bezglebowe, to owady mają wysoką wydajność konwersji paszy, średnio $2 \mathrm{~kg}$ paszy na $1 \mathrm{~kg}$ masy owadów ${ }^{37}$. Mogą być one postrzegane jako alternatywa konwencjonalnej żywności, stanowiąca zarazem bogate źródło białka, kwasów tłuszczowych i mikroelementów, takich jak żelazo, magnez i selen ${ }^{38}$. Uprawy i hodowle bezglebowe są niezależne od warunków pogo-

${ }^{30}$ E. Obłuska, Hydroponika jako odpowiedź na problemy wspótczesnego rolnictwa, https:// ecoreactor.org/hydroponika/ [dostęp: 19.03.2021].

${ }^{31}$ A. van Huis, J. van Itterbeeck, H. Klunder, E. Mertens, A. Halloran, G. Muir, P. Vantomme, Edible insects: future prospects for food and feed security, Rome 2013, s. 13.

32 Odpowiedź na interpelację nr 12115, s. 1.

${ }^{33}$ E. Obłuska, Hydroponika jako odpowiedź...

${ }^{34}$ N. Sharma, S. Acharya, K. Kumar, N. Singh, O.P. Chaurasia, Hydroponics as an advanced technique for vegetable production: An overview, ,Journal of Soil and Water Conservation” 2018, nr 17(4), s. 366.

${ }^{35}$ E. Obłuska, Hydroponika jako odpowiedź...

${ }^{36}$ N. Sharma, S. Acharya, K. Kumar, N. Singh, O.P. Chaurasia, Hydroponics as an advanced technique..., s. 366.

${ }^{37}$ Podczas gdy produkcja bydła wymaga $8 \mathrm{~kg}$ paszy na $1 \mathrm{~kg}$ przyrostu masy ciała, por. T. Laaninen, Insects..., s. 1.

${ }^{38} \mathrm{FAO}$, The contribution of insects to food security, livelihoods and the environment, http:// www.fao.org/docrep/018/i3264e/i3264e00.pdf [dostęp: 19.03.2021]. 
dowych i klimatycznych ${ }^{39}$. Mogą więc pełnić szczególną rolę w miejscach, gdzie występuje duży stres środowiskowy, np. na pustyniach, na bardzo zimnych lub gorących obszarach ${ }^{40}$.

Metody te pozwalają efektywniej wykorzystywać zasoby, w tym wodę i nawozy, wpisując się w zasady gospodarki o obiegu zamkniętym. Systemy cyrkularne pozwalają bowiem zachować zasoby w obrębie gospodarki ${ }^{41}$. Warte podkreślenia jest zwłaszcza niewydostawanie się wody z obiegu procesu wytwarzania ${ }^{42}$. W przypadku hydroponiki pozwala to na ograniczenie zużycia wody nawet o $90 \% \mathrm{w}$ porównaniu do tradycyjnego rolnictwa ${ }^{43}$. W uprawach o obiegu zamkniętym także składniki odżywcze wykorzystywane są wielokrotnie i nie przedostają się do gleby. Zwiększa to produktywność zasobów i umożliwia realizację celu UE i państw członkowskich w zakresie zasobooszczędności ${ }^{44}$. Pozwala to również lepiej kontrolować gospodarkę odpadami i ograniczać uwalnianie do środowiska dużych ilości azotanów i fosforanów z nawozów ${ }^{45}$. Natomiast hodowla insektów wytwarza mniej gazów cieplarnianych i amoniaku oraz zużywa znaczniej mniej wody niż hodowla zwierząt gospodarskich ${ }^{46}$.

Uprawy bezglebowe czy hodowla owadów pozwalają też ograniczyć ilość wykorzystywanych gruntów rolnych. Dla przykładu, hydroponika wymaga nawet pięć razy mniej przestrzeni niż uprawa tej samej ilości roślin na gruntach rolnych ${ }^{47}$. W dodatku nie muszą one mieć charakteru rolnego. Te metody upraw lub hodowli mogą być stosowane np. w halach przemysłowych. Pozwala to na lokalizację produkcji rolnej w miejscach najbardziej potrzebnych, w tym w pobliżu ośrodków miejskich, co może także przynosić korzyści ekonomiczne i środowiskowe, tj. minimalizować koszty i negatywny wpływ na środowisko związane z możliwością ograniczenia

${ }^{39}$ N. Sharma, S. Acharya, K. Kumar, N. Singh, O.P. Chaurasia, Hydroponics as an advanced technique..., s. 366.

40 Ibidem, s. 366.

${ }^{41}$ Komunikat Komisji do Parlamentu Europejskiego, Rady, Europejskiego Komitetu Ekonomiczno-Społecznego i Komitetu Regionów: Ku gospodarce o obiegu zamkniętym: program „zero odpadów dla Europy”, $\operatorname{COM(2014)~} 398$ final, s. 2.

${ }^{42}$ E. Obłuska, Hydroponika jako odpowiedź....

${ }^{43}$ N. Sharma, S. Acharya, K. Kumar, N. Singh, O.P. Chaurasia, Hydroponics as an advanced technique..., s. 369.

${ }^{44}$ Komunikat Komisji do Parlamentu Europejskiego, Rady, Europejskiego Komitetu Ekonomiczno-Społecznego i Komitetu Regionów: Ku gospodarce..., s. 16.

${ }^{45}$ E. Obłuska, Hydroponika jako odpowiedź...

${ }^{46}$ T. Laaninen, Insects..., s. 1.

${ }^{47}$ H. Fitzpatrick, 5 Environmental Benefits of Hydroponic Growing (Explained in Detail), https://get-green-now.com/hydroponics-environmental-benefits/ [dostęp: 19.03.2021]. 
dalekiego transportu żywności ${ }^{48}$. Oszczędność zasobów oraz ograniczenie wykorzystywania gruntów skutkowało nawet rozpoczęciem wykorzystywania hydroponiki przez NASA na Międzynarodowej Stacji Kosmicznej ${ }^{49}$.

W literaturze podkreśla się również, że hydroponika ogranicza u roślin ryzyko chorób glebowych, infekcji przenoszonych przez owady lub szkodniki, a chwasty prawie nie występują, co ma zarazem wpływ na zmniejszenie ilości stosowanych pestycydów ${ }^{50}$.

\section{Ekonomiczne, społeczne oraz prawne ograniczenia w wykorzystywaniu upraw i hodowli bezglebowych na cele żywnościowe}

Mimo wielu zalet bezglebowej uprawy i hodowli nie są one stosowane na dużą skalę. Bariery w stosowaniu tych metod mają głównie charakter ekonomiczny, społeczny i prawny. Jeśli chodzi o względy ekonomiczne, to rozwiązania te generują wysokie początkowe nakłady kapitałowe ${ }^{51}$. Są one także związane z koniecznością zdobycia odpowiedniej wiedzy technicznej, stosowania bardzo zaawansowanej technologii, a niekiedy cyfryzacji procesów wytwórczych ${ }^{52}$. Automatyzacja procesów oznacza też znacznie zwiększone koszty związane $z$ dostawą energii elektrycznej ${ }^{53}$, zwłaszcza gdy systemy są sztucznie ogrzewane albo chłodzone ${ }^{54}$. Ewentualne przerwy w dostawach prądu mogą uniemożliwić uzyskanie przewidywanych plonów ${ }^{55}$. W związku z tym żywność produkowana przy zastosowaniu tych technologii jest droższa niż tradycyjna żywność ${ }^{56}$.

Warto również pokreślić trudność i stopień skomplikowania bezglebowych systemów upraw i hodowli. Pierwszorzędne znaczenie dla produkcji ma ciągłe podtrzymywanie wytworzonych na potrzeby stosowanych procesów

${ }^{48}$ E. Obłuska, Hydroponika jako odpowiedź...

$49 \mathrm{https} / / /$ sitn.hms.harvard.edu/flash/2019/hydroponics-the-power-of-water-to-grow-food/ [dostęp: 19.03.2021].

${ }^{50}$ N. Sharma, S. Acharya, K. Kumar, N. Singh, O.P. Chaurasia, Hydroponics as an advanced technique..., s. 366.

${ }^{51}$ Odpowiedź na interpelację nr 12115, s. 1.

${ }^{52}$ N. Sharma, S. Acharya, K. Kumar, N. Singh, O.P. Chaurasia, Hydroponics as an advanced technique..., s. 366.

${ }_{53}$ E. Obłuska, Hydroponika jako odpowiedź...

${ }^{54}$ Odpowiedź na interpelację nr 12115, s. 1.

${ }^{55} \mathrm{http}$ ://hydrogrow.pl/zalety-i-wady/ [dostęp: 19.03.2021].

${ }^{56} \mathrm{https} / / / \mathrm{sitn} . \mathrm{hms}$.harvard.edu/flash/2019/hydroponics-the-power-of-water-to-grow-food/ [dostęp: 19.03.2021]. 
sztucznych warunków, w szczególności temperatury, natlenienia, wilgotności, kwasowości, stężenia pożywki, źródła światła ${ }^{57}$. O ile rozwiązania te pozwalają ograniczyć ryzyko występowania „,chorób glebowych” i inwazji szkodników, o tyle drobnoustroje rozwijające się w zamkniętym obiegu stanowią zagrożenie dla całej uprawy lub hodowli ${ }^{58}$. Przykładowo, rośliny w systemie hydroponicznym wykorzystują ten sam składnik odżywczy, a choroby przenoszone przez wodę mogą łatwo rozprzestrzeniać się wśród roślin $^{59}$. Jeden patogen może zatem stanowić zagrożenie dla całej uprawy. $\mathrm{Z}$ tego powodu niezbędne jest ciągłe monitorowanie strefy korzeniowej roślin ${ }^{60}$ i dbanie o dobrą jakość wody ${ }^{61}$.

Jeżeli chodzi o kwestie społeczne, to innowacyjna żywność, w tym wytworzona przy zastosowaniu nowych metod produkcyjnych lub niespożywana dotychczas na konkretnym obszarze geograficznym lub w określonym kręgu kulturowym, może mieć istotny wpływ na zachowania i decyzje konsumentów. Warto zauważyć, że tylko nieliczna grupa konsumentów szybko przekonuje się do innowacji ${ }^{62}$. Nowość zazwyczaj jest postrzegana przez pryzmat związanego z nią ryzyka ${ }^{63}$. Neofobia żywieniowa, która oznacza niechęć do spożywania nowej żywności lub jej unikanie ${ }^{64}$, nie jest zjawiskiem charakterystycznym tylko dla małych dzieci. Wysoki poziom neofobii żywieniowej spotyka się u 10-25\% badanych konsumentów, w zależności od wieku, przy czym w największym stopniu dotyczy to osób w wieku 15-19 lat oraz powyżej 50 lat ${ }^{65}$. Wydaje się zatem, że powszechna akceptacja niektórych nowych rozwiązań w rolnictwie lub nowych środków spożywczych wymaga czasu na adaptację przez konsumentów oraz zmianę ich nawyków żywieniowych.

${ }^{57}$ N. Sharma, S. Acharya, K. Kumar, N. Singh, O.P. Chaurasia, Hydroponics as an advanced technique..., s. 366.

${ }^{58}$ E. Obłuska, Hydroponika jako odpowiedź...

${ }^{59}$ N. Sharma, S. Acharya, K. Kumar, N. Singh, O.P. Chaurasia, Hydroponics as an advanced technique..., s. 366 .

${ }^{60} \mathrm{https}$ :/www.growtent.pl/Uprawa-hydroponiczna-czy-jest-lepsza-niz-standardowe-sposoby-uprawy-blog-pol-1571044678.html [dostęp: 19.03.2021].

${ }^{61} \mathrm{http}: / /$ hydrogrow.pl/zalety-i-wady/ [dostęp: 19.03.2021].

${ }^{62}$ Chodzi o posiadanie cechy innowacyjności, przez którą należy rozumieć krótki czas potrzebny do przyswojenia nowości. Por. badania na temat innowacyjności konsumentów: M. Jeżewska-Zychowicz, E. Babicz-Zielińska, W. Laskowski, Konsument na rynku nowej żywności. Wybrane uwarunkowania spożycia, Warszawa 2009, s. 164.

${ }^{63}$ Ibidem, s. 177.

${ }^{64}$ P. Pliner, K. Hobden, Development of measures of food neophobia in children, „Appetite” 1992, nr 23, s. 147 i n.

${ }^{65}$ E. Jeżewska-Zychowicz, E. Babicz-Zielińska, W. Laskowski, Konsument na rynku ..., s. $160-161$. 
Jeśli natomiast chodzi o względy prawne, to istnieje wiele barier prawnych, które ograniczają atrakcyjność stosowania upraw bezglebowych.

Żywność wytworzona dzięki zastosowaniu tego rodzaju technologii może stanowić nową żywność, czyli środki spożywcze, które nie mają historii bezpiecznego stosowania w UE i należą do jednej z prawnie wydzielonych kategorii $^{66}$. Pierwsze kryterium klasyfikacji produktu jako nowej żywności zakłada, że nie stosowano go w znacznym stopniu w UE do spożycia przez ludzi przed 15 maja 1997 r., niezależnie od dat przystąpienia państw członkowskich do $\mathrm{UE}^{67}$. Według drugiego kryterium w kontekście upraw i hodowli bezglebowych należy wyróżnić trzy grupy środków spożywczych, które zaliczają się do novel food. Po pierwsze, jest to żywność składająca się, wyekstrahowana lub produkowana z roślin lub ich części, z wyjątkiem żywności mającej historię bezpiecznego stosowania żywności w Unii i składającej się, wyekstrahowanej lub produkowanej z rośliny lub odmiany tego samego gatunku uzyskanych: tradycyjnymi metodami rozmnażania stosowanymi do produkcji żywności w Unii przed 15 maja 1997 r. lub nietradycyjnymi metodami rozmnażania, które nie były stosowane do produkcji żywności w Unii przed 15 maja 1997 r., jeżeli metody te nie powodują znaczących zmian w składzie lub strukturze żywności, mających wpływ na jej wartość odżywczą, metabolizm lub poziom substancji niepożądanych. Po drugie, jest to żywność składająca się, wyekstrahowana lub produkowana ze zwierząt lub ich części, z wyjątkiem zwierząt wyhodowanych tradycyjnymi metodami stosowanymi do produkcji żywności w Unii przed 15 maja 1997 r., jeżeli żywność uzyskana z tych zwierząt posiada historię bezpiecznego stosowania żywności w Unii. Po trzecie, jest to żywność uzyskana z wykorzystaniem procesu produkcji niestosowanego w Unii przed 15 maja 1997 r., który to proces produkcji powoduje znaczące zmiany w składzie lub strukturze żywności, mające wpływ na jej wartość odżywczą, metabolizm lub poziom substancji niepożądanych.

Ocena, czy dany środek spożywczy stanowi nową żywność, musi być dokonywana indywidualnie w każdym konkretnym przypadku. I tak, żywność powstała przy wykorzystaniu niektórych metod, np. hydroponiki, nie będzie zazwyczaj stanowić nowej żywności, ponieważ żywność uzyskana w ten sposób od dawna znana jest i stosowana w UE, choć nie zawsze na skalę masową. Inne środki spożywcze stanowią natomiast novel food,

${ }^{66} \mathrm{~V}$. Amanor-Boadu, Post-market surveillance model for potential human health effects of novel foods, ,Food Policy” 2004, nr 29, s. 611.

${ }_{67}$ Zob. art. 3 ust. 2 lit. a) rozporządzenia Parlamentu Europejskiego i Rady (UE) nr 2015/2283 z 25 listopada 2015 r. w sprawie nowej żywności, zmieniającego rozporządzenie Parlamentu Europejskiego i Rady (UE) nr 1169/2011 oraz uchylającego rozporządzenie (WE) nr 258/97 Parlamentu Europejskiego i Rady oraz rozporządzenie Komisji (WE) nr 1852/2001 (Dz. Urz. UE L 2015, nr 327, s. 1; dalej: rozporządzenie nr 2015/2283). 
np. owady. Podkreślił to również prawodawca w preambule do rozporządzenia nr 2015/2283, wskazując, że kategorie żywności będącej nową żywnością obejmują również całe owady i ich części ${ }^{68}$, których hodowla nie wymaga udziału gruntów rolnych.

Kwalifikacja środka spożywczego jako nowej żywności wiąże się z koniecznością przeprowadzenia przez podmiot prowadzący przedsiębiorstwo spożywcze ${ }^{69}$ przedrynkowej oceny bezpieczeństwa produktu, weryfikowanej $\mathrm{w}$ ramach przewidzianych $\mathrm{w}$ unijnych regulacjach procedur. Wprowadzenie do obrotu w UE tego rodzaju produktów zależy od spełnienia szczegółowych wymogów prawnych oraz uzyskania zezwolenia, co stanowi bardzo kosztowną i czasochłonną inwestycję.

Postępowanie w sprawie dopuszczenia nowej żywności do obrotu generuje znaczne koszty. Niektóre źródła podają, że wynoszą one od 300 tys. do 4 mln euro ${ }^{70}$. Wzorcowe postępowanie w sprawie wydania zezwolenia na wprowadzanie nowej żywności na rynek unijny powinno toczyć się nie dłużej niż 18 miesięcy $^{71}$. W rzeczywistości jednak proces wprowadzania nowej żywności na rynek unijny może być wydłużany. Rozporządzenie nr 2015/2283 przewiduje bowiem wiele możliwości wydłużania terminów, zarówno w celu uzyskania dodatkowych informacji od wnioskodawcy, jak i ad hoc. W tej drugiej sytuacji jedynym wymogiem są bliżej niesprecyzowane wyjątkowe okoliczności.

W obecnym stanie prawnym wprowadzanie nowej żywności na rynek, stanowiące kosztowne i czasochłonne inwestycje, może być traktowane przez mniejszych przedsiębiorców jako nieatrakcyjne i nieuzasadnione ekonomicznie. Takie stwierdzenie poparte jest stosunkowo niewielką liczbą złożonych wniosków o wydanie zezwolenia na wprowadzanie nowej żywności na rynek unijny. Według art. 26 rozporządzenia nr 2015/2283 czynnikiem zniechęcającym do prowadzenia działalności innowacyjnej jest również możliwość wykorzystywania osiągnięć konkretnych podmiotów przez pozostałych uczestników rynku, najpóźniej po upływie określonego w decyzji Komisji

${ }^{68}$ Pkt 8 preambuły do rozporządzenia $\mathrm{nr} 2015 / 2283$.

${ }_{69}$ Zgodnie z art. 3 pkt 3 rozporządzenia Parlamentu Europejskiego i Rady (WE) nr 178/2002 z 28 stycznia 2002 r. ustanawiającego ogólne zasady i wymagania prawa żywnościowego, powołującego Europejski Urząd ds. Bezpieczeństwa Żywności oraz ustanawiającego procedury w zakresie bezpieczeństwa żywności (Dz. Urz. UE L 2002, nr 31, s. 1 ze zm.), podmiot prowadzący przedsiębiorstwo spożywcze oznacza osoby fizyczne lub prawne odpowiedzialne za spełnienie wymogów prawa żywnościowego w przedsiębiorstwie spożywczym pozostającym pod ich kontrolą.

${ }^{70}$ J. Krakowiak, Wprowadzanie na rynek tzw. nowej żywności, http://www.codozasady.pl/ wprowadzanie-na-rynek-tzw-nowej-zywnosci/ [dostęp: 19.03.2021].

${ }^{71}$ I. Härtel, H. Yu, Food Security and Food Safety Law, w: I. Härtel (red.) Handbook of AgriFood Law in China, Germany, European Union, New York 2018, s. 87. 
okresu ochrony danych naukowych, który nie może trwać dłużej niż 5 lat. Po upływie tego terminu każdy może korzystać z wydanego zezwolenia na wprowadzanie nowej żywności na rynek unijny.

Trzeba zauważyć, że konsumenci coraz częściej poszukują żywności określonego rodzaju i o szczególnych właściwościach. Jednak w odniesieniu do żywności pochodzącej z upraw lub hodowli bezglebowych istnieją znaczne ograniczenia w zakresie certyfikowania ich jakości handlowej. $\mathrm{Na}$ przykład unijne regulacje ograniczają możliwość wprowadzania tego rodzaju środków spożywczych jako produktów ekologicznych ${ }^{72}$.

Według rozporządzenia $\mathrm{nr}$ 2018/848 ${ }^{73}$, które obowiązuje od 1 stycznia 2021 r., ekologiczne rośliny uprawne, z wyjątkiem tych, które rosną w sposób naturalny w wodzie, są produkowane w żywej glebie lub żywej glebie zmieszanej z materiałami i produktami dozwolonymi w produkcji ekologicznej lub nimi nawożonej w powiązaniu z podglebiem i skałą macierzystą $^{74}$. Za podstawę ekologicznej produkcji roślinnej przyjmuje się odżywianie roślin przede wszystkim przez ekosystem gleby, zatem rośliny powinny być uprawiane na i w żywej glebie w powiązaniu z podglebiem i skałą macierzystą, a w związku z tym w ramach produkcji ekologicznej nie powinna być dozwolona produkcja hydroponiczna ani uprawa roślin w pojemnikach, workach lub na podłożach, w przypadku gdy korzenie nie mają kontaktu z żywą glebą ${ }^{75}$.

Od tej zasady istnieją jednak pewne wyjątki. W ramach produkcji ekologicznej dozwolone są np. praktyki polegające na uprawie roślin ozdobnych i ziół w doniczkach, które mają być sprzedawane konsumentowi końcowemu wraz z doniczką, oraz uprawa siewek lub sadzonek w pojemnikach do dalszego przesadzania. W takim bowiem przypadku nie ma ryzyka, że konsument zostanie wprowadzony w błąd co do metody produkcji ${ }^{76}$.

Warto podkreślić, że zasada ekologicznej uprawy roślin na gruntach rolnych oraz odżywianie ich poprzez ekosystem gleby została ustanowiona w regulacjach obowiązujących do końca 2020 r. $^{77}$ Mimo to na mocy rozpo-

${ }^{72} \mathrm{https}$ //ec.europa.eu/info/food-farming-fisheries/farming/organic-farming/organic-production-and-products_pl, [dostęp: 19.03.2021].

${ }^{73}$ Pkt 1.1. części I załącznika nr II do rozporządzenia Parlamentu Europejskiego i Rady (UE) nr 2018/848 z 30 maja 2018 r. w sprawie produkcji ekologicznej i znakowania produktów ekologicznych i uchylającego rozporządzenie Rady (WE) nr 834/2007 (Dz. Urz. UE L 2018, nr 150, s. 1, dalej: rozporządzenie $\mathrm{nr}$ 2018/848).

74 Ibidem.

${ }_{75}$ Pkt 28 preambuły do rozporządzenia nr 2018/848.

${ }^{76}$ Pkt 29 preambuły do rozporządzenia nr 2018/848.

77 Przede wszystkim w rozporządzeniu Rady (WE) nr 834/2007 z 28 czerwca 2007 r. w sprawie produkcji ekologicznej i znakowania produktów ekologicznych i uchylające rozporządzenie (EWG) nr 2092/91 (Dz. Urz. UE L 2007, nr 189, s. 1 ze zm.). 
rządzenia nr 834/2007 organy administracji publicznej niektórych państw członkowskich certyfikowały uprawę bezglebową roślin na wyniesionych zagonach jako ekologiczną ${ }^{78}$. Z informacji przekazanych Komisji przez państwa członkowskie wynikało, że taka działalność była dopuszczona w Unii przed 28 czerwca 2017 r. jedynie w Finlandii, Szwecji i Danii ${ }^{79}$.

Porozumienie wypracowane 28 czerwca 2017 r. w ramach zwykłej procedury ustawodawczej ostatecznie przesądziło jednak o tym, że produkcja ekologiczna powinna opierać się na odżywianiu roślin przede wszystkim poprzez ekosystem gleby i powinna mieć miejsce na podłożu glebowym, a uprawy bezglebowe roślin na wyniesionych zagonach nie powinny już od tej daty być dozwolone w ramach produkcji ekologicznej ${ }^{80}$. Aby zapewnić podmiotom, które przed tą datą podjęły taką działalność, możliwość dostosowania się do przyjętych rozwiązań, prawodawca umożliwił w ramach produkcji ekologicznej uprawę bezglebową na wyniesionych zagonach wyłącznie na powierzchniach, które zostały certyfikowane jako ekologiczne dla tych praktyk przed 28 czerwca 2017 r. w Finlandii, Szwecji i Danii ${ }^{81}$. Nie jest dozwolone żadne powiększenie tych powierzchni. Odstępstwo to przestanie obowiązywać 31 grudnia $2030 \mathrm{r}^{82}$

Co do ekologicznej produkcji zwierzęcej, to z wyjątkiem pszczelarstwa zabrania się produkcji zwierzęcej bez gruntów rolnych w przypadku, gdy rolnik zamierzający prowadzić ekologiczną produkcję zwierzęcą nie gospodaruje gruntami rolnymi ani nie zawarł pisemnej umowy o współpracy z innym rolnikiem, jeśli chodzi o stosowanie ekologicznych jednostek produkcyjnych lub jednostek produkcyjnych w okresie konwersji dla tych zwierząt gospodarskich $^{83}$. Wymóg ten wyraża przekonanie, że produkcja zwierząt gospodarskich jest naturalnie związana $\mathrm{z}$ gospodarowaniem gruntami rolnymi, a obornik wykorzystywany jest do nawożenia wspomagającego produkcję roślin ${ }^{84}$.

Zapotrzebowanie na innowacyjne rozwiązania $\mathrm{w}$ rolnictwie jest ogromne wobec coraz większego popytu na żywność oraz w związku z postępującymi zmianami klimatu, dlatego każda technologia, która jest pomocna w rozwiązywaniu problemów współczesnego rolnictwa, zasługuje na uwagę ${ }^{85}$. W ramach WPR szczególne znaczenie przypisuje się rozwijaniu systemów wiedzy i innowacji w dziedzinie rolnictwa, stymulowaniu inicjowania i rozwoju

\footnotetext{
${ }^{78}$ Pkt 30 preambuły do rozporządzenia nr 2018/848.

79 Ibidem.

${ }^{80}$ Ibidem.

${ }^{81}$ Pkt 1.5. części I załącznika nr II do rozporządzenia nr 2018/848.

82 Ibidem.

83 Pkt 1.1. części II załącznika nr II do rozporządzenia nr 2018/848.

${ }^{84}$ Pkt 40 preambuły do rozporządzenia nr 2018/848.

${ }^{85}$ Odpowiedź na interpelację nr 12115, s. 2.
} 
innowacyjnych projektów, rozpowszechnianiu ich osiągnięć i wykorzystywaniu ich $\mathrm{w}$ jak najszerszym zakresie ${ }^{86}$. Wiedza i innowacje mają bowiem istotne znaczenie dla kreatywnego, stabilnego i zrównoważonego sektora rolnictwa, a przyszła WPR ma sprzyjać zwiększaniu inwestycji w badania naukowe i innowacje oraz pozwoli rolnikom i społecznościom wiejskim czerpać z nich większe korzyści ${ }^{87}$.

Trzeba stwierdzić, że stosowanie bezglebowych metod uprawy i hodowli może się przyczynić do realizacji celu 2 „Wyeliminować głód, osiągnąć bezpieczeństwo żywnościowe i lepsze odżywianie oraz promować zrównoważone rolnictwo" rezolucji przyjętej przez Zgromadzenie Ogólne ONZ 25 września 2015 r. ${ }^{88}$ Zakłada on m.in. wyeliminowanie do 2030 r. głodu i wszystkich form niedożywienia, zapewnienie wszystkim ludziom dostępu do bezpiecznej i pożywnej żywności w wystarczającej ilości.

Mimo to prawodawca nie przewiduje żadnych systemów wsparcia dla podmiotów zamierzających wprowadzać żywność wytworzoną w oparciu o uprawy lub hodowle bezglebowe. Przyjęte strategie i programy polityczne zakładające zwiększenie innowacyjności gospodarki w zasadzie pomijają to zagadnienie. Ze względu na duże zasoby ziemi uprawnej i potencjał produkcyjny nie przewiduje się bowiem, by uprawy bezglebowe w Polsce były wiodącym kierunkiem rozwoju rolnictwa ${ }^{89}$. Mogą one być raczej stosowane jako jedna $\mathrm{z}$ alternatyw w przypadku upraw warzyw albo kwiatów, w szczególności na terenach gęsto zaludnionych, na których brakuje miejsca na działalność rolniczą z użyciem gleby ${ }^{90}$.

$\mathrm{W}$ odpowiedzi na interpelację nr $12115 \mathrm{w}$ sprawie wprowadzenia na większą skalę praw hydroponicznych stwierdzono, że uprawy hydroponiczne, będąc tylko cennym uzupełnieniem rolnictwa tradycyjnego, nie stanowią alternatywy dla tradycyjnej uprawy drzew i krzewów owocowych, roślin oleistych, okopowych oraz zbóż ${ }^{91}$. Dlatego powinny być traktowane jak każda inna działalność biznesowa podlegająca prawom rynku, wymagająca nakładów i rachunku ekonomicznego, a ich ewentualne wsparcie trudno powiązać ze wsparciem, jakie należne jest tradycyjnym formom gospodarowania rolniczego ${ }^{92}$.

\footnotetext{
${ }^{86} \mathrm{https} / / /$ ec.europa.eu/info/food-farming-fisheries/key-policies/common-agricultural-policy/ future-cap_pl\#innovation [dostęp: 19.03.2021].

${ }^{87}$ Ibidem.

${ }^{88}$ Rezolucja przyjęta przez Zgromadzenie Ogólne ONZ w dniu 25 września 2015 r. Przekształcamy nasz świat: Agenda na rzecz zrównoważonego rozwoju 2030, s. 17 i n.

${ }^{89}$ Odpowiedź na interpelację nr 12115, s. 2.

${ }^{90}$ Ibidem, s. 3-4.

${ }^{91}$ Ibidem, s. 4.

92 Ibidem, s. 3.
} 
Czynnikiem wykorzystywania w rolnictwie bezglebowych metod upraw lub hodowli są zatem jedynie korzyści ekonomiczne, jakie mogą odnieść podmioty korzystające $\mathrm{z}$ tych rozwiązań.

\section{Podsumowanie}

Udzielając odpowiedzi na zadane na wstępie pytanie, trzeba stwierdzić, że mimo coraz szerszego stosowania bezglebowych metod upraw i hodowli konieczna i w pełni uzasadniona jest prawna ochrona gruntów rolnych w celu zapewnienia możliwości prowadzenia produkcji rolnej, a w konsekwencji zagwarantowania bezpieczeństwa żywnościowego, również w aspekcie własnościowym, określonym w ustawie o kształtowaniu ustroju rolnego.

Choć coraz częściej wykorzystuje się metody upraw i hodowli, które nie wymagają udziału gleby, to grunty rolne nadal są podstawowym i niezbędnym czynnikiem produkcji rolnej. W obecnej sytuacji społeczno-gospodarczej, przy uwzględnieniu uwarunkowań ekonomicznych, społecznych, środowiskowych i prawnych, należy stwierdzić, że rozwiązania te nie zastąpią tradycyjnego rolnictwa. Mogą je natomiast wspomagać, stanowiąc uzupełnienie tradycyjnej produkcji rolnej, zwłaszcza na obszarach gęsto zaludnionych lub takich, na których występuje duży stres środowiskowy.

Mając jednak na uwadze wyzwania współczesności związane z potrzebą zapewnienia bezpieczeństwa żywnościowego, konieczne jest rozwijanie nowych, wydajnych metod produkcji rolnej, niezależnych od zmian klimatycznych, warunków atmosferycznych, a jednocześnie sprzyjających środowisku, a co za tym idzie - stworzenie warunków prawnych służących wsparciu innowacyjności w sektorze rolno-spożywczym. Należy jednak mieć na względzie to, by żywność pochodząca z innowacyjnych upraw albo hodowli lub wytwarzana przy zastosowaniu nowych technologii produkcyjnych nie stanowiła zagrożenia dla życia i zdrowia ludzi, których ochrona jest podstawowym celem prawa żywnościowego.

\section{BIBLIOGRAFIA}

Amanor-Boadu V. (2004), Post-market surveillance model for potential human health effects of novel foods, „Food Policy” nr 29.

Budzinowski R. (2015), Współczesne wyzwania związane z żywnościa i ich rola $w$ ksztaltowaniu polityki rolnej i prawa rolnego, „Przegląd Prawa Rolnego” nr 2.

Czechowski P., Marciniuk K. (2019), w: P. Czechowski (red.), Prawo rolne, Warszawa. 
Fitzpatrick H. (2018), 5 Environmental Benefits of Hydroponic Growing (Explained in Detail), https://get-green-now.com/hydroponics-environmental-benefits/ [dostęp: 19.03.2021].

Härtel I., Yu H. (2018), Food Security and Food Safety Law, w: I. Härtel (red.), Handbook of Agri-Food Law in China, Germany, European Union, New York.

Huis A. van, Itterbeeck J. van, Klunder H., Mertens E., Halloran A., Muir G., Vantomme P. (2013), Edible insects: future prospects for food and feed security, Rome.

Insect Protein - Feed for the Future, http://www.proteinsect.eu/fileadmin/user_upload/press/ proteinsect-whitepaper-2016.pdf [dostęp: 19.03.2021].

Iwiński M., Zydroń A., Antkowiak M., Szczepański P. (2017), Wpływ nowelizacji ustawy o ksztaltowaniu ustroju rolnego na rynek nieruchomości rolnych w województwie wielkopolskim, „Studia i Prace Wydziału Nauk Ekonomicznych i Zarządzania” nr 49(1).

Jeżewska-Zychowicz M., Babicz-Zielińska E., Laskowski W. (2009), Konsument na rynku nowej żywności. Wybrane uwarunkowania spożycia, Warszawa.

Jeżyńska B., Pastuszko R. (2012), Ramy prawne obrotu nieruchomościami rolnymi po 2016 roku. Opinie i ekspertyzy, Warszawa.

Kozłowska K. (2016), Ocena wybranych aspektów innowacyjności polskich przedsiębiorstw, w: P. Urbanek, E. Walińska (red.), Ekonomia i zarządzanie w teorii i praktyce. Ekonomia i nauki o zarzadzaniu w warunkach integracji gospodarczej, Łódź.

Krakowiak J. (2011), Wprowadzanie na rynek tzw. nowej żywności, http://www.codozasady. pl/wprowadzanie-na-rynek-tzw-nowej-zywnosci/ [dostęp: 19.03.2021].

Kurowska T. (2014), Renesans własności rolniczej, „Przegląd Prawa Rolnego” nr 2.

Laaninen T., Insects - soon to be a regulated food?, EPRS (European Parliamentary Research Service), Members' Research Service PE 583.830,

Leśkiewicz K. (2012), Bezpieczeństwo żywnościowe i bezpieczeństwo żywności - aspekty prawne, „Przegląd Prawa Rolnego” nr 1.

Leśkiewicz K.. (2020), Prawo żywnościowe, Warszawa.

Litwiniuk P. (2019), Ochrona własności rolniczej w świetle ustawy o ksztaltowaniu ustroju rolnego, „Przegląd Prawa Rolnego” nr 2.

Marks-Bielska R., Bieniek A. (2018), Ekonomiczne i środowiskowe aspekty obrotu ziemia rolnicza w Polsce, „Studia Obszarów Wiejskich” t. 50.

Obłuska E. (2020), Hydroponika jako odpowiedź na problemy współczesnego rolnictwa, https://ecoreactor.org/hydroponika/ [dostęp: 19.03.2021].

Pliner P., Hobden K. (1992), Development of measures of food neophobia in children, „Appetite" nr 23.

Schumpeter J.A. (1960), Teoria wzrostu gospodarczego, Warszawa.

Sharma N., Acharya S., Kumar K., Singh N., Chaurasia O.P. (2018), Hydroponics as an advanced technique for vegetable production: An overview, „Journal of Soil and Water Conservation" nr 17(4).

Sokołowski Ł.M. (2017), Entomofagia w świetle regulacji dotyczacych nowej żywnościwybrane aspekty prawne, „Przegląd Prawa Rolnego” nr 1. 


\title{
SOILLESS CROPS AND FARMS \\ AND THE NEED TO PROTECT AGRICULTURAL LAND FROM THE PERSPECTIVE OF ENSURING FOOD SECURITY
}

\author{
Summary
}

The aim of this paper was to examine whether, despite the increasing use of soilless methods of cultivation and breeding, legal protection of agricultural land is still justified in view of the need to ensure food security. Despite the fact that the use of cultivation and breeding methods that do not require soil has been on the increase, agricultural land remains a basic and indispensable factor of agricultural production. It must be stated that in the current socio-economic situation the new technologies cannot replace traditional agriculture. They may, however, support it by complementing traditional agricultural production, particularly in densely populated areas or in areas where the environmental stress is high. For this reason, legal protection of agricultural land is necessary and fully justified as it ensures agricultural production and, consequently, guarantees food security, also in the ownership aspect as defined in the Act on shaping the agricultural system.

Keywords: soilless crops, soilless culture, entomophagy, hydroponics, aeroponics, novel food, organic food, food security

\section{LE COLTIVAZIONI E ALLEVAMENTI SENZA TERRA E LA PROTEZIONE DEI FONDI AGRICOLI DAL PUNTO DI VISTA DELLA SICUREZZA ALIMENTARE}

\author{
Riassunto
}

L'articolo si propone di rispondere alla domanda se, nonostante un crescente utilizzo di metodi di coltivazione e allevamento senza terra, la tutela giuridica dei terreni agricoli, tenuto conto della necessità di garantire la sicurezza alimentare, sia sempre giustificata. Sebbene i metodi di coltivazione e allevamento che non richiedono la terra siano sempre più presenti, si deve riconoscere che il terreno agricolo rimanga essenziale e necessario per la produzione agricola. Nell'attuale situazione socioeconomica, le tecnologie in oggetto non riusciranno a sostituire l'agricoltura tradizionale, anche se possono servire da supporto, integrando la produzione agricola tradizionale, in particolare nelle aree densamente popolate e a elevato stress ambientale. Per questo motivo la tutela giuridica dei terreni agricoli è necessaria e del tutto giustificata, specie se si tratta di assicurare la produzione agricola e, di conseguenza, la sicurezza alimentare, anche dal punto di vista della proprietà, così come essa è stata specificata nella legge sul regime agrario.

Parole chiave: coltivazioni senza terra, allevamenti senza terra, entomofagia, idroponica, aeroponica, novel food, alimenti biologici, sicurezza alimentare 